\title{
Is Bartonella a Cause of Primary Sclerosing Cholangitis? A Case Study
}

\author{
Daniel A. Kinderlehrer
}

668 South Newport Street, Denver, CO 80224, USA; kinderlehrer@gmail.com

Received: 11 November 2019; Accepted: 6 March 2020; Published: 9 March 2020

\begin{abstract}
The etiology of primary sclerosing cholangitis (PSC) is unknown. I present a case which may be indicative of a causal link between Bartonella infection and PSC. The patient presented with complaints of abdominal pain and bloody diarrhea. A colonoscopy demonstrated chronic inflammation and changes consistent with ulcerative colitis. Routine laboratory studies revealed elevated liver function tests (LFTs); ultrasound and magnetic resonance imaging (MRI) confirmed the diagnosis of PSC. Bartonella serology was positive. It is established that Bartonella infection is associated with both gastrointestinal inflammation and autoimmunity; indeed, there is an animal model for Bartonella-induced PSC. Bartonella is susceptible to treatment with vancomycin and there are case reports and small series that demonstrate that PSC responds to treatment with oral vancomycin. Because of this, it is postulated that at least some cases of PSC may be associated with Bartonella infection. The patient in this report was treated with oral vancomycin and, since then, has been in remission for both colitis and PSC. Since vancomycin is not systemically absorbed, the premise is that he suffered from Bartonella colitis and an autoimmune reaction to Bartonella causing PSC. This premise warrants further study.
\end{abstract}

Keywords: bartonella; primary sclerosing cholangitis; autoimmune; colitis

\section{Introduction}

Primary sclerosing cholangitis (PSC) is a chronic liver disease characterized by a progressive course of cholestasis with inflammation and fibrosis of the intrahepatic and extrahepatic biliary tree. The etiology of PSC is unknown but is postulated to be autoimmune [1]. While immunosuppressive agents have not been effective in the treatment of PSC, antibiotics have shown promise. In particular, vancomycin has demonstrated efficacy in multiple case reports and small series [2].

Bartonella henselae (B. henselae) is the causative agent of cat scratch disease (CSD) as well as a wide array of systemic infections, including colitis [3]. Arthropod vectors, including Ixodes ticks, can transmit Bartonella spp., and can co-infect patients with Lyme disease [4,5]. I present a case of a thirteen-year-old immunocompetent male with a previous history of Lyme disease who developed colitis and PSC. He had a positive serology to B. henselae and Bartonella quintana (B. quintana), suggesting the role of Bartonella in the pathogenesis of these conditions.

\section{Case Presentation}

This male patient initially presented at nine years of age with multisystem symptoms. At four years of age he developed an Erythema Migrans (EM) rash while in Maryland and was diagnosed by a medical practitioner as having Lyme disease. The patient was put on an antibiotic but discontinued it after four days. Subsequent to this episode, he began complaining of severe leg pains, sleep disturbances and mood swings with dramatic temper tantrums. Gradually, he developed other symptoms, including intermittent knee pains, inguinal pain, back pain, neck pain, and ear pain. He had one episode of 
tachycardia with dyspnea and chest pain lasting thirty minutes; the cardiac evaluation was negative. When his handwriting began to deteriorate, his parents brought him in for evaluation.

The family did not own a cat. A review of the systems was otherwise negative and physical examination was unremarkable. Laboratory evaluation was significant for the presence of Lyme Western Blot immunoglobulin G (IgG) bands 39 and 41.

The patient was treated with oral amoxicillin $500 \mathrm{mg}$ three times daily for six months and symptoms remitted. Four years later, the patient developed fatigue and intermittent abdominal pain with frequent soft bowel movements and some blood in his stools. Three months later, his symptoms worsened and his weight had dropped by four pounds. Investigation at that time revealed:

- Iron deficiency anemia:

Hemoglobin $=10.6 \mathrm{~g} / \mathrm{dL}$ (reference range (RR): 13.5-17.7 g/dL);

O Hematocrit $=35 \%$ (RR: $37-49 \%$ );

- Ferritin $=14 \mathrm{ng} / \mathrm{mL}$ (RR: $47-356 \mathrm{ng} / \mathrm{mL}$ ).

- Increased inflammatory markers:

Leukocytosis $\mathrm{WBC}=13,600 / \mathrm{uL}$ (RR: 4000-11,000/uL);

○ $\quad \mathrm{ESR}=41 \mathrm{~mm} / \mathrm{hr}($ RR: $0-20 \mathrm{~mm} / \mathrm{hr}$ );

○ Faecal calprotectin $=188 \mathrm{mg} / \mathrm{kg}$ (RR: $<50 \mathrm{mg} / \mathrm{kg})$.

- Elevated liver enzymes in a cholestatic pattern:

Alkaline phosphatase $=1117 \mathrm{U} / \mathrm{L}(\mathrm{RR}: 98-448 \mathrm{U} / \mathrm{L})$;

Aspartate aminotransferase $=121 \mathrm{U} / \mathrm{L}(\mathrm{RR}: 6-38 \mathrm{U} / \mathrm{L})$;

Alanine aminotransferase $=207 \mathrm{U} / \mathrm{L}(\mathrm{RR}: 13-63 \mathrm{U} / \mathrm{L})$;

- Gamma glutamyltransferase $=457 \mathrm{U} / \mathrm{L}(\mathrm{RR}: 6-75 \mathrm{U} / \mathrm{L})$.

- Immunologic testing:

Total IgG $=1800 \mathrm{mg} / \mathrm{dL}$ (RR: 681-1648);

Anti-tissue transglutaminase $\mathrm{IgA}=1.9 \mathrm{U} / \mathrm{mL}(\mathrm{RR}: 0-19 \mathrm{U} / \mathrm{mL})$;

0 Anti-gliadin antibody $\operatorname{IgA}=0.2(\mathrm{U} / \mathrm{mL})(\mathrm{RR}: 0-20 \mathrm{U} / \mathrm{mL})$;

Antinuclear antibody (ANA) negative (RR: negative);

- Anticytoplasmic antibody negative (RR: negative);

Smooth muscle antibody negative (RR: negative);

Anti-liver kidney microsome antibody-1 $=0.8 \mathrm{U}$ (RR: 0-20 U);

$\bigcirc$ Myeloperoxidase antibody $<0.2$ (RR: $0.0-0.9$ );

○ C-anti-neutrophil cytoplasmic antibody $=1: 640$ (RR: $<1: 20)$.

- Thiopurine $S$-methyltransferase gene variants: none detected;

- Serological testing of IgG to Bartonella henselae and Bartonella quintana by enzyme linked immunofluorescence assay (ELISA) were both elevated at 1:256 (RR: non-reactive);

- Serum PCR testing for Bartonella species was negative;

- A colonoscopy revealed a diffuse area of moderately congested, erythematous, friable and inflamed mucosa in the rectum, the recto-sigmoid colon, the sigmoid colon, the descending colon and at the splenic flexure (see Figure 1). A biopsy revealed mild active inflammation with mild architectural changes;

- An abdominal ultrasound showed dilation of the distal common bile duct measuring $7.3 \mathrm{~mm}$; hepatic enlargement measuring $17.8 \mathrm{~cm}$ sagitally (RR: $8.7-13.7 \mathrm{~cm}$ ); the liver was mildly echogenic; the remainder of the ultrasound was normal; 
- An MRI with magnetic resonance cholangiopancreatography (MRCP) showed slight beading of the common bile duct, common hepatic duct, and proximal hepatic duct; the common bile duct was dilated to $10 \mathrm{~mm}$ in width (see Figure 2).

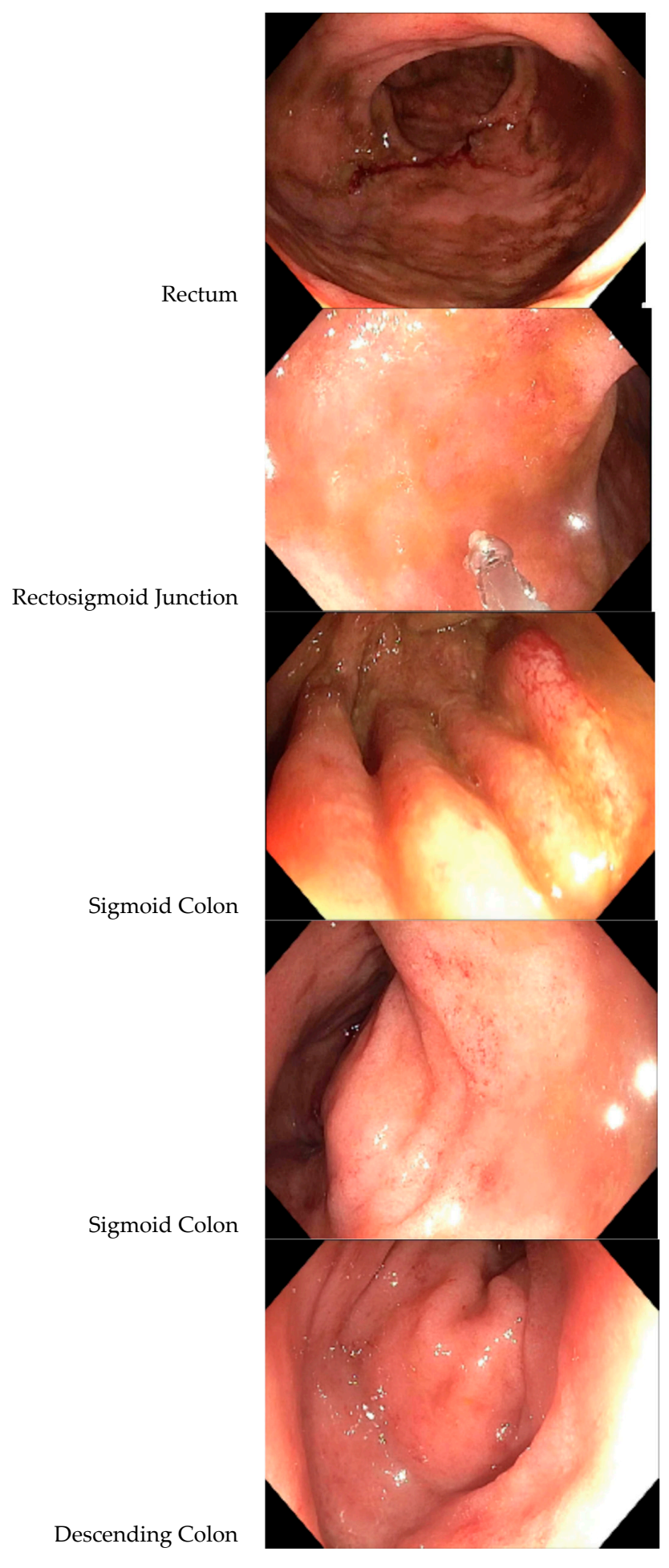

Figure 1. Cont. 


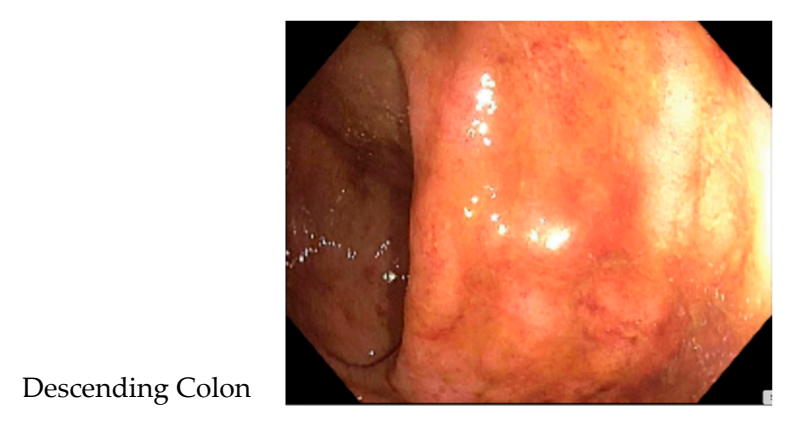

Figure 1. Colonoscopy at presentation.

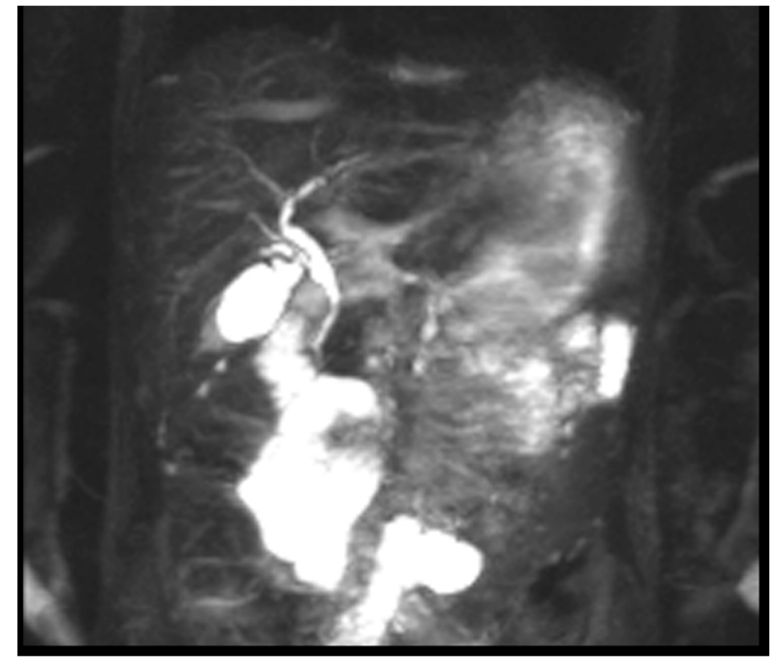

Figure 2. Magnetic resonance cholangiopancreatography (MRCP) at presentation.

The patient was treated with mesalamine $400 \mathrm{mg}$ three times daily. His diarrhea slowed but did not resolve and he continued to complain of abdominal pain. After three weeks on mesalamine, he began oral vancomycin $500 \mathrm{mg}$ three times daily. After one month on oral vancomycin, all symptoms remitted. All laboratory abnormalities returned to normal, including faecal calprotectin. A repeat MRCP showed the common bile duct had decreased to $7 \mathrm{~mm}$ in width, and beading had decreased (see Figure 3). Repeat Bartonella serology and PCR testing of the colonic biopsy is not available.

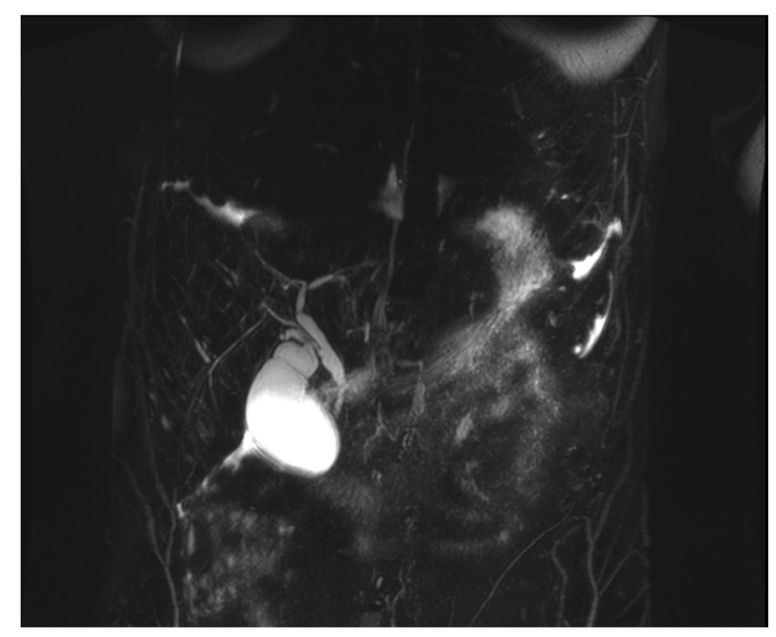

Figure 3. MRCP after one year of treatment. 


\section{Discussion}

PSC has an estimated prevalence of $16.2 / 100,000$ in the total adult population; male 22.7/100,000 and female 8.9/100,000 [6]. PSC most often occurs in young males and is associated with a high incidence of inflammatory bowel disease, primarily ulcerative colitis. PSC is complicated by cancer-cholangiocarcinoma, gallbladder carcinoma and colorectal carcinoma-in 13\%-14\% of patients [7].

The etiology of PSC is unknown, but is postulated to be autoimmune because of its increased frequency with the presence of autoimmune antibodies and autoimmune illnesses, pathological findings of immune cells, particularly lymphocytes, its strong linkage to the histocompatibility complex (HLA) and the prevalence of non-HLA genome-wide single nucleotide polymorphisms [1].

Several therapeutic modalities, including ursodeoxycholic acid and immunosuppressive agents, have failed to alter the course of PSC. While liver transplants may extend lifespan, the recurrence rate is high [1]. However, antibiotics have shown promise. Cox et al. described three adolescent males with PSC and Crohn's disease whose hepatic enzymes and liver biopsies normalized on oral vancomycin [8]. Davies et al. treated fourteen patients with PSC with oral vancomycin, all of whom improved; however, four patients with previously diagnosed cirrhosis showed less improvement than those without cirrhosis [9]. Tabibian et al. randomized thirty-five patients with PSC into four groups: vancomycin $125 \mathrm{mg}$ or $250 \mathrm{mg}$ four times per day and metronidazole $250 \mathrm{mg}$ or $500 \mathrm{mg}$ three times per day; all groups improved but the vancomycin groups showed the greatest improvement [10]. In a triple-blinded, randomized, placebo-controlled trial of twenty-nine patients, of which eighteen were treated with oral vancomycin $125 \mathrm{mg}$ four times daily for twelve weeks, Rahimpour et al. found that vancomycin significantly reduced the PSC Mayo risk scores as well as the levels of alkaline phosphatase [11]. Dao et al. described improvements in both ulcerative colitis and PSC in eight patients, five of whom had undergone liver transplant, when treated with oral vancomycin $125 \mathrm{mg}$ four times daily for 6-8 weeks, after which the dose was tapered but not discontinued; all patients maintained endoscopic response/remission [12]. Tan et al. described the impact of oral vancomycin on seventeen children with ulcerative colitis and PSC, in which they stated: "There was a striking response of colitis with near universal colonic healing" [13]. Additional case reports have cited the efficacy of vancomycin in the treatment of PSC [14-16]. All of these reports are small and predominantly in children or adolescents. Nevertheless, a review article on vancomycin in the treatment of PSC concludes "Vancomycin is one of the most-studied antibiotics in the treatment of PSC with promising results" [2].

Since oral vancomycin is not systemically absorbed, its efficacy has been attributed to working as both an antibiotic and immunomodulator, possibly by modifying the gut microbiome [17,18]. An alternative explanation is that an autoimmune reaction triggered by a Bartonella infection in the intestines could precipitate PSC.

Bartonella is a small, aerobic, intracellular gram-negative pleomorphic bacillus. The bacillus is difficult to grow; hence, culture is not recommended [19]. A polymerase chain reaction (PCR) in blood or tissue specimens is the most definitive way to diagnose bartonellosis; however, this method lacks sensitivity $(43 \%-76 \%)$ [20]. Serological testing by either indirect immunoflouresent assay (IFA) or ELISA is the standard tool to diagnose B. henselae, although increased sensitivity of antibody assays is associated with decreased specificity [21]. Giladi et al. reported 77\% sensitivity of the second of the paired samples IgG by ELISA in patients with CSD documented by positive PCR [22]. Sander et al. reported $100 \%$ positive IgG serology in patients with CSD, but also found 30\% of controls were seropositive [23]. There is no data on the sensitivity or specificity of serologic testing in patients with Bartonella infections acquired via tick transmission. Bartonella spp. other than B. henselae and B. quintana have caused infection in humans [24], which may account for false negative serologies when testing for only the above two Bartonella spp.

While it is not known how this patient became infected with Bartonella, it is notable that a variety of arthropod vectors may be implicated. B. henselae is the causative agent of cat scratch disease (CSD), 
transmitted via the cat flea. It is well established that Bartonella spp. can also be transmitted by sandflies and lice [25] and, while the transmission of Bartonella spp. via a tick vector has been debated, there is direct evidence that $B$. henselae can be transmitted via the Ixodes tick $[4,5]$. Co-occurrence of Bartonella spp. with known tick-borne pathogens, such as Borrelia burgdorferi (B. burgdorferi) sensu lato may not be uncommon. Adelson et al. surveyed Ixodes ticks in northern New Jersey and found B. burgdorferi present in 35\% of ticks while 34\% harbored Bartonella spp. [26]. Additional studies have confirmed the high incidence of Bartonella spp. in Ixodes ticks $[27,28]$. Several case studies of patients with $B$. burgdorferi infection of the central nervous system after tick bites have demonstrated concurrent Bartonella seropositivity confirmed by detection of Bartonella spp. DNA in their blood $[29,30]$.

Bartonella spp. are responsible for a wide spectrum of clinical illness in humans, including disseminated infection and septicemia, neurological, cardiovascular, ocular, musculoskeletal, and cutaneous disease [31]. In addition, $B$. henselae can infect the gastrointestinal tract and cause ulcerative colitis $[3,32]$.

Bartonella can also induce autoimmune disease [33]. Bartonella has been associated with autoimmune thyroiditis [34], autoimmune hemolytic anemia [35], juvenile rheumatoid arthritis [36], IgA nephropathy [37,38], arthropathies [39-41], polyneuropathy [40,42], Guillain-Barré syndrome [43], chronic vasculitis [37,42], immune thrombocytopenic purpura [44], transverse myelitis [45] and Henoch-Schönlein purpura [46,47].

The pathogenesis of autoimmune diseases involves the interplay of genetic and environmental factors [48]. The pathogenic mechanism(s) by which Bartonella causes autoimmune disorders may be caused by cross-reactivity or molecular mimicry [49], polyclonal $\mathrm{T}$ cell activation by bacterial antigens [50], activation of the classical complement cascade-producing proinflammatory cytokines [51], or the formation of immune complexes which precipitate in various tissues, resulting in an inflammatory response [52]. Bartonella can induce cellular immune stimulation resulting in granuloma formation and lymphocyte and neutrophil accumulations in various tissues [53].

There are no previous reports of an association between Bartonella infection and PSC in humans, but there are in cats. Kordeck et al. reported the results of inoculating eighteen specific pathogen-free cats that were culture and serologically negative for Bartonella with the blood or urine of cats infected with B. henselae and/or Bartonella clarridgeiae (B. clarridgeiae). Thirteen cats were euthanized and nine had evidence of cholangitis/pericholangitis with lymphocytic infiltration and plasma cells [54]. These pathological findings are the same as in patients with PSC.

The case presented here suggests, but does not prove, the causal association of Bartonella in the pathogenesis of PSC. The patient had a well-documented case of Lyme disease, with a history of an EM rash in an endemic area for Lyme disease treated inadequately and followed by multisystem symptoms and a Western Blot IgG positive for bands 39 and 41. Band 39 is highly specific for B. burgdorferi [55]. While this patient's Western Blot did not meet the Centers for Disease Control and Prevention (CDC) criteria for reporting Lyme disease, the CDC criteria are intended for surveillance purposes only, and are not intended to make a clinical diagnosis $[56,57]$.

When the patient was initially treated for infection with B. burgdorferi, he may have been co-infected with a Bartonella infection via the same tick vector. The history of severe mood swings is particularly suggestive of infection with Bartonella [58]. Treatment of B. burgdorferi infection with amoxicillin could suppress a Bartonella infection without eradicating the microbe, since Bartonella is somewhat susceptible to beta-lactam antibiotics [59]. In any case, three years later, positive antibody titers in this patient documented exposure to Bartonella spp. when he developed colitis and PSC. The hepatic ultrasound showed echogenic areas that could represent granulomas associated with Bartonella infection [53]. Bartonella spp. have high in vitro susceptibilities to vancomycin [59] and could treat Bartonella colitis. Since oral vancomycin is not systemically absorbed, the implication is that treating the infection reversed an autoimmune response that resulted in PSC.

Several investigators have posited that vancomycin's capacity to treat PSC is due, in part, to its action as an immunomodulator. [18] While the impact of vancomycin on patients with PSC leads 
to decreased inflammatory parameters [11,18], vancomycin could also mitigate inflammation if it is treating the microbial trigger of an autoimmune reaction. Howden et al. demonstrated that the development of low-level vancomycin resistance in methicillin resistant Staphylococcus aureus is associated with changes in nuclear factor kappa-light-chain-enhancer of activated B cells (NF- $\mathrm{kB}$ ) and decreased tumor necrosis factor-alpha (TNF- $\alpha$ ) [60]; however, this decrease in the host pro-inflammatory response to infection is not evidence that vancomycin is an immune modulator. Furthermore, multiple trials of immunosuppressive therapy with glucocorticoids and several chemotherapeutic agents have not led to improvement in patients with PSC [1]. The findings in this patient are consistent with B. henselae as a cause of colitis and as the trigger of an autoimmune response resulting in PSC.

\section{Conclusions}

This case raises the possibility that Bartonella infection in the colon could trigger an autoimmune response leading to PSC. Given the serious morbidity and mortality of this illness, the implications are significant for promoting future research. Further studies, such as PCR testing of serum and tissue samples, as well as testing of patients with PSC for Bartonella spp. compared with a control population, would help determine the role of Bartonella in the etiology of PSC.

Conflicts of Interest: The author declares no conflict of interest.

\section{Abbreviations}

$\begin{array}{ll}\text { PSC } & \text { Primary sclerosing cholangitis } \\ \text { LFT } & \text { Liver function test } \\ \text { HLA } & \text { Histocompatibility-complex } \\ \text { CSD } & \text { Cat scratch disease } \\ \text { EM } & \text { Erythema migrans } \\ \text { IgG } & \text { Immunoglobulin G } \\ \text { IFA } & \text { Indirect immunoflourescence assay } \\ \text { MRI } & \text { Magnetic resonance imaging } \\ \text { MRCP } & \text { Magnetic resonance cholangiopancreatography } \\ \text { ELISA } & \text { Enzyme linked immunoassay } \\ \text { CDC } & \text { Centers for Disease Control and Prevention } \\ \text { RR } & \text { Reference range } \\ \text { B. henselae } & \text { Bartonella henslae } \\ \text { B. quintana } & \text { Batronella quintana } \\ \text { B. burgdorferi } & \text { Borrellia burgdorferi } \\ \text { B. clarridgeiae } & \text { Bartonella clarridgeiae } \\ \text { NF- } \mathrm{B} \text { N } & \text { Nuclear factor kappa-light-chain-enhancer of activated B cells } \\ \text { TNF- } \alpha & \text { Tumor necrosis factor-alpha }\end{array}$

\section{References}

1. Goode, E.; Rushbrook, S. A review of the medical treatment of primary sclerosing cholangitis in the 21st century. Ther. Adv. Chronic Dis. 2015, 7, 68-85. [CrossRef] [PubMed]

2. Damman, J.; Rodriguez, E.; Ali, A.; Buness, C.; Cox, K.; Carey, E.; Lindor, K.D. Review article: The evidence that vancomycin is a therapeutic option for primary sclerosing cholangitis. Aliment. Pharmacol. Ther. 2018, 47, 886-895. [CrossRef] [PubMed]

3. Massei, F.; Massimetti, M.; Messina, F.; Macchia, P.; Maggiore, G. Bartonella henselae and inflammatory bowel disease. Lancet 2000, 356, 1245-1246. [CrossRef]

4. Reis, C.; Cote, M.; Le Rhun, D.; Lecuelle, B.; Levin, M.; Vayssier-Taussat, M.; Bonnet, S.I. Vector Competence of the Tick Ixodes ricinus for Transmission of Bartonella birtlesii. PLoS Negl. Trop. Dis. 2011, 5, e1186. [CrossRef]

5. Cotté, V.; Bonnet, S.; Le Rhun, D.; Le Naour, E.; Chauvin, A.; Boulouis, H.-J.; Lecuelle, B.; Lilin, T.; Vayssier-Taussat, M. Transmission of Bartonella henselae by Ixodes ricinus. Emerg. Infect. Dis. 2008, 14, 1074-1080. [CrossRef] 
6. Liang, H.; Manne, S.; Shick, J.; Lissoos, T.; Dolin, P. Incidence, prevalence, and natural history of primary sclerosing cholangitis in the United Kingdom. Medicine 2017, 96, e7116. [CrossRef] [PubMed]

7. Bonato, G.; Cristoferi, L.; Strazzabosco, M.; Fabris, L. Malignancies in Primary Sclerosing Cholangitis-A Continuing Threat. Dig. Dis. 2015, 33, 140-148. [CrossRef]

8. Cox, K.; Cox, K. Oral Vancomycin: Treatment of Primary Sclerosing Cholangitis in Children. J. Pediatric Gastroenterol. Nutr. 1997, 25, 479. [CrossRef]

9. Davies, Y.; Cox, K.; Abdullah, B.; Safta, A.; Terry, A.; Cox, K. Long-term Treatment of Primary Sclerosing Cholangitis in Children With Oral Vancomycin: An Immunomodulating Antibiotic. J. Pediatric Gastroenterol. Nutr. 2008, 47, 61-67. [CrossRef]

10. Tabibian, J.; Weeding, E.; Jorgensen, R.; Petz, J.; Keach, J.; Talwalkar, J.; Lindor, K.D. Randomized clinical trial: Vancomycin or metronidazole in patients with primary sclerosing cholangitis-A pilot study. Aliment. Pharmacol. Ther. 2013, 37, 604-612. [CrossRef]

11. Rahimpour, S.; Nassiri-Toosi, M.; Khalili, H.; Daryani, N.E.; Taromlou, M. A Triple Blinded, Randomized, Placebo-Controlled Clinical Trial to Evaluate the Efficacy and Safety of Oral Vancomycin in Primary Sclerosing Cholangitis: A Pilot Study. J. Gastrointest. Liver Dis. 2016, 25, 457-464.

12. Dao, A.; Abidian, M.; Lestrange, A.; Matter, M.; Rangnekar, A.; Charabaty, A. Oral Vancomycion Induces and Maintains Remission of Ulcerative Colitis in the Subset of Patients with Associated Primary Sclerosing Cholangitis. Inflamm. Bowel Dis. Lett. 2019, 25, e90-e91. [CrossRef] [PubMed]

13. Tan, L.-Z.; Reilly, C.R.; Steward-Harrison LCBalouch, F.; Muir, R.; Lewindon, P.J. Oral vancomycin induces clinical and mucosal remission of colitis in children with primary sclerosing cholangitis-ulcerative colitis. Gut 2019, 68, 1533-1535. [CrossRef]

14. Hey, P.; Lokan, J.; Johnson, P.; Gow, P. Efficacy of oral vancomycin in recurrent primary sclerosing cholangitis following liver transplantation. Br. Med. J. Case Rep. 2017. [CrossRef] [PubMed]

15. Buness, C.; Lindor, K.; Miloh, T. Oral Vancomycin Therapy in a Child with Primary Sclerosing Cholangitis and Severe Ulcerative Colitis. Pediatric Gastroenterol. Hepatol. Nutr. 2016, 19, 210. [CrossRef] [PubMed]

16. Davies, Y.; Tsay, C.; Caccamo, D.; Cox, K.; Castillo, R.; Cox, K. Successful Treatment of Recurrent Primary Sclerosing Cholangitis after Orthotopic Liver Transplantation with Oral Vancomycin. Case Rep. Transplant. 2013, 2013, 1-5. [CrossRef] [PubMed]

17. Tabibian, J.; O'Hara, S.; Lindor, K. Primary sclerosing cholangitis and the microbiota: Current knowledge and perspectives on etiopathogenesis and emerging therapies. Scand. J. Gastroenterol. 2014, 49, 901-908. [CrossRef] [PubMed]

18. Abarbanel, D.; Seki, S.; Davies, Y.; Marlen, N.; Benavides, J.; Cox, K.; Nadeau, K.C.; Cox, K.L. Immunomodulatory Effect of Vancomycin on Treg in Pediatric Inflammatory Bowel Disease and Primary Sclerosing Cholangitis. J. Clin. Immunol. 2012, 33, 397-406. [CrossRef]

19. La Scola, B.; Raoult, D. Culture of Bartonella quintana and Bartonella henselae from Human Samples: A 5-Year Experience (1993 to 1998). J. Clin. Microbiol. 1999, 37, 1899-1905. [CrossRef]

20. Sander, A.; Posselt, M.; Böhm, N.; Ruess, M.; Altwegg, M. Detection of Bartonella henselae DNA by Two Different PCR Assays and Determination of the Genotypes of Strains Involved in Histologically Defined Cat Scratch Disease. J. Clin. Microbiol. 1999, 37, 993-997. [CrossRef]

21. Vermeulen, M.; Herremans, M.; Verbakel, H.; Bergmans, A.; Roord, J.; van Dijken, P.; Peeters, M.F. Serological testing for Bartonella henselae infections in The Netherlands: Clinical evaluation of immunofluorescence assay and ELISA. Clin. Microbiol. Infect. 2007, 13, 627-634. [CrossRef]

22. Giladi, M.; Kletter, Y.; Avidor, B.; Metzkor-Cotter, E.; Varon, M.; Golan, Y.; Weinberg, M.; Riklis, I.; Ephros, M.; Leonard, S. Enzyme Immunoassay for the Diagnosis of Cat-Scratch Disease Defined by Polymerase Chain Reaction. Clin. Infect. Dis. 2001, 33, 1852-1858. [CrossRef] [PubMed]

23. Sander, A.; Posselt, M.; Oberle, K.; Bredt, W. Seroprevalence of antibodies to Bartonella henselae in patients with cat scratch disease and in healthy controls: Evaluation and comparison of two commercial serological tests. Clin. Diagn. Lab. Immunol. 1998, 5, 486-490. [CrossRef] [PubMed]

24. Okaro, U.; Addisu, A.; Casanas, B.; Anderson, B. Bartonella Species, an Emerging Cause of Blood-CultureNegative Endocarditis. Clin. Microbiol. Rev. 2017, 30, 709-746. [CrossRef] [PubMed]

25. Billeter, S.; Levy, M.; Chomel, B.; Breitschwerdt, E. Vector transmission of Bartonella species with emphasis on the potential for tick transmission. Med. Vet. Entomol. 2008, 22, 1-15. [CrossRef] 
26. Adelson, M.; Rao, R.; Tilton, R.; Cabets, K.; Eskow, E.; Fein, L.; Occi, J.L.; Mordechai, E. Prevalence of Borrelia burgdorferi, Bartonella spp; Babesia microti, and Anaplasma phagocytophila in Ixodes scapularis Ticks Collected in Northern New Jersey. J. Clin. Microbiol. 2004, 42, 2799-2801. [CrossRef]

27. Holden, K.; Boothby, J.; Kasten, R.; Chomel, B. Co-detection of Bartonella henselae, Borrelia burgdorferi, and Anaplasma phagocytophilum in Ixodes pacificus Ticks from California, USA. Vector Borne Zoonotic Dis. 2006, 6, 99-102. [CrossRef]

28. Halos, L.; Jamal, T.; Maillard, R.; Beugnet, F.; Le Menach, A.; Boulouis, H.; Vayssier-Taussat, M. Evidence of Bartonella sp. in questing adult and nymphal Ixodes ricinus ticks from France and co-infection with Borrelia burgdorferi sensu lato and Babesia sp. Vet. Res. 2005, 36, 79-87. [CrossRef]

29. Eskow, E.; Rao, R.; Mordechai, E. Concurrent Infection of the Central Nervous System by Borrelia burgdorferi and Bartonella henselae. Arch. Neurol. 2001, 58, 1357. [CrossRef]

30. Podsiadly, E.; Chmielewski, T.; Tylewska-Wierzbanowska, S. Bartonella henselae and Borrelia burgdorferi Infections of the Central Nervous System. Ann. N. Y. Acad. Sci. 2003, 990, 404-406. [CrossRef]

31. Rolain, J.; Brouqui, P.; Koehler, J.; Maguina, C.; Dolan, M.; Raoult, D. Recommendations for Treatment of Human Infections Caused by Bartonella Species. Antimicrob. Agents Chemother. 2004, 48, 1921-1933. [CrossRef] [PubMed]

32. Fried, M.; Schairer, J.; Madigan, G.; Ball, A. Bartonella henselae is associated with heartburn, abdominal pain, skin rash, mesenteric adenitis, gastritis and duodenitis. J. Pediatric Gastroenterol. Nutr. 2002, 35, 158.

33. Maritsi, D.; Zarganis, D.; Metaxa, Z.; Papaioannou, G.; Vartzelis, G. Bartonella henselae Infection: An Uncommon Mimicker of Autoimmune Disease. Case Rep. Pediatrics 2013, 2013, 1-4. [CrossRef] [PubMed]

34. Chiuri, R.; Matronola, M.; Di Giulio, C.; Comegna, L.; Chiarelli, F.; Blasetti, A. Bartonella henselae Infection Associated with Autoimmune Thyroiditis in a Child. Horm. Res. Paediatr. 2013, 79, 185-188. [CrossRef] [PubMed]

35. Van Audenhove, A.; Verhoef, G.; Peetermans, W.; Boogaerts, M.; Vandenberghe, P. Autoimmune haemolytic anaemia triggered by Bartonella henselae infection: A case report. Br. J. Haematol. 2001, 115, 924-925. [CrossRef] [PubMed]

36. Tsukahara, M.; Tsuneoka, H.; Tateishi, H.; Fujita, K.; Uchida, M. Bartonella Infection Associated with Systemic Juvenile Rheumatoid Arthritis. Clin. Infect. Dis. 2001, 32, e22-e23. [CrossRef]

37. Cozzani, E.; Cinotti, E.; Ameri, P.; Sofia, A.; Murialdo, G.; Parodi, A. Onset of cutaneous vasculitis and exacerbation of IgA nephropathy after Bartonella henselae infection. Clin. Exp. Dermatol. 2011, 37, 238-240. [CrossRef]

38. Hopp, L.; Eppes, S. Development of IgA nephritis following cat scratch disease in a 13-year-old boy. Pediatric Nephrol. 2004, 19, 682-684. [CrossRef]

39. Giladi, M.; Maman, E.; Paran, D.; Bickels, J.; Comaneshter, D.; Avidor, B.; Varon-Graidy, M.; Ephros, M.; Wientroub, S. Cat-scratch disease-associated arthropathy. Arthritis Rheum. 2005, 52, 3611-3617. [CrossRef]

40. Beard, C.B.; Nelson, C.A.; Mead, P.S.; Petersen, L.R.; Raoult, D.; Maggi, R.G.; Mozayeni, B.R.; Pultorak, E.L.; Hegarty, B.C.; Bradley, J.M.; et al. Bartonella spp. Bacteremia and Rheumatic Symptoms in Patients from Lyme Disease-endemic Region. Emerg. Infect. Dis. 2012, 18, 1919-1921.

41. Durey, A.; Kwon, H.; Im, J.; Lee, S.; Baek, J.; Han, S.; Kang, J.-S.; Lee, J.-S. Bartonella henselae infection presenting with a picture of adult-onset Still's disease. Int. J. Infect. Dis. 2016, 46, 61-63. [CrossRef] [PubMed]

42. Stockmeyer, B.; Schoerner, C.; Frangou, P.; Moriabadi, T.; Heuss, D.; Harrer, T. Chronic Vasculitis and Polyneuropathy due to Infection with Bartonella henselae. Infection 2007, 35, 107-109. [CrossRef] [PubMed]

43. Massei, F.; Gori, L.; Taddeucci, G.; Macchia, P.; Maggiore, G. Bartonella henslae infection associated with Guillain-Barre syndrome. Pediatric Infect. Dis. J. 2006, 25, 90-91. [CrossRef] [PubMed]

44. Palumbo, E.; Sodini, F.; Boscarelli, G.; Nasca, G.; Branchi, M.; Pellegrini, G. Immune thrombocytopenic purpura as a complication of Bartonella henselae infection. Le Infezioni Medicina 2008, 2, 99-102.

45. Baylor, P.; Garoufi, A.; Karpathios, T.; Lutz, J.; Mogelof, J.; Moseley, D. Transverse Myelitis in 2 Patients With Bartonella henselae Infection (Cat Scratch Disease). Clin. Infect. Dis. 2007, 45, e42-e45. [CrossRef]

46. Ayoub, E.; McBride, J.; Schmiederer, M.; Anderson, B. Role of Bartonella henselae in the etiology of Henoch-Schönlein purpura. Pediatric Infect. Dis. J. 2002, 21, 28-31. [CrossRef]

47. Robinson, J.; Spady, D.; Prasad, E.; McColl, D.; Artsob, H. Bartonella seropositivity in children with Henoch-Schonlein purpura. BMC Infect. Dis. 2005, 5, 21. [CrossRef] 
48. Ceccarelli, F.; Agmon-Levin, N.; Perricone, C. Genetic Factors of Autoimmune Diseases. J. Immunol. Res. 2016, 2016, 1-2. [CrossRef]

49. Rashid, T.; Ebringer, A. Autoimmunity in Rheumatic Diseases Is Induced by Microbial Infections via Crossreactivity or Molecular Mimicry. Autoimmune Dis. 2012, 2012, 1-9. [CrossRef]

50. Granholm, N.; Cavallo, T. Autoimmunity, Polyclonal B-Cell Activation and Infection. Lupus 1992, 1, 63-74. [CrossRef]

51. Lintner, K.; Wu, Y.; Yang, Y.; Spencer, C.; Hauptmann, G.; Hebert, L.; Atkinson, J.P.; Yu, Y. Early Components of the Complement Classical Activation Pathway in Human Systemic Autoimmune Diseases. Front. Immunol. 2016, 7, 36. [CrossRef] [PubMed]

52. Mayadas, T.; Tsokos, G.; Tsuboi, N. Mechanisms of Immune Complex-Mediated Neutrophil Recruitment and Tissue Injury. Circulation 2009, 120, 2012-2024. [CrossRef] [PubMed]

53. Ventura, A.; Massei, F.; Not, T.; Massimetti, M.; Bussani, R.; Maggiore, G. Systemic Bartonella henselae Infection with Hepatosplenic Involvement. J. Pediatric Gastroenterol. Nutr. 1999, 29, 52-56. [CrossRef] [PubMed]

54. Kordick, D.; Brown, T.; Shin, K.; Breitschwerdt, E. Clinical and pathologic evaluation of chronic Bartonella henslae or Bartonella clarridgiae infection in cats. J. Clin. Microbiol. 1999, 37, 1536-1547. [CrossRef]

55. Ma, B.; Christen, B.; Leung, D.; Vigo-Pelfrey, C. Serodiagnosis of Lyme borreliosis by western immunoblot: Reactivity of various significant antibodies against Borrelia burgdorferi. J. Clin. Microbiol. 1992, 30, 370-376. [CrossRef]

56. Surveillance Case Definitions|NNDSS [Internet]. Available online: https://wwwn.cdc.gov/nndss/casedefinitions.html (accessed on 14 February 2020).

57. Case Definitions for Infectious Conditions under Public Health Surveillance. In Morbidity and Mortality Weekly Report; CDC: Atlanta, GA, USA, 1997; p. 46(RR10).

58. Breitschwerdt, E.; Sontakke, S.; Hopkins, S. Neurological Manifestations of Bartonellosis in Immunocompetent Patients: A Composite of Reports from 2005-2012. J. Neuroparasitol. 2012, 3, 1-15. [CrossRef]

59. Sobraquès, M.; Maurin, M.; Birtles, R.; Raoult, D. In Vitro Susceptibilities of Four Bartonella bacilliformis Strains to 30 Antibiotic Compounds. Antimicrob. Agents Chemother. 1999, 43, 2090-2092. [CrossRef]

60. Howden, B.; Smith, D.; Mansell, A.; Johnson, P.; Ward, P.; Stinear, T.; Davies, J.K. Different bacterial gene expression patterns and attenuated host immune responses are associated with the evolution of low-level vancomycin resistance during persistent methicillin-resistant Staphylococcus aureus bacteraemia. BMC Microbiol. 2008, 8, 39. [CrossRef] 